\title{
Researching Teaching Self-Efficacy of Pre-School Teachers
}

\author{
Margarita Atsoniou \\ Early Childhood Teacher, Sifnos, Greece \\ Email: m.atsonou4@gmail.com
}

How to cite this paper: Atsoniou, M. (2020) Researching Teaching Self-Efficacy of Pre-School Teachers. Open Access Library Journal, 7: e6447.

https://doi.org/10.4236/oalib.1106447

Received: May 20, 2020

Accepted: June 12, 2020

Published: June 15, 2020

Copyright $\odot 2020$ by author(s) and Open Access Library Inc.

This work is licensed under the Creative Commons Attribution International License (CC BY 4.0).

http://creativecommons.org/licenses/by/4.0/

\section{(c) (i) Open Access}

\begin{abstract}
The present research was carried out in the framework of the undergraduate program of pedagogy and more specifically pre-school education of the Metropolitan College. The choice of the topic that will be analyzed below was made with the help of Mrs. Haritakis, whom I had the honor to have as my supervisor, but also out of my own interest because I always wanted to learn how each teacher sees his work and whether he considers it that he is doing it right. In order to be able to carry out this research, quantitative research was used, in which an attempt was made to capture the opinion of fifty (40) pre-school teachers about their teaching self-efficacy. The tool used to conduct the research was the Teaching Efficacy Instrument (Teachers Sense of Efficacy Scale [TSES] [1], which was applied to 40 pre-school teachers. The overall purpose of this research is to investigate the self-efficacy of preschool teachers in relation to classroom management, student engagement and teaching strategies. The findings of this study will help educational research to reduce the lack of knowledge on this issue.
\end{abstract}

\section{Subject Areas}

Education

\section{Keywords}

Teaching Self-Efficacy, Pre-school Teachers, Student Involvement, Teaching Strategies, Classroom Management

\section{Introduction}

In the context of the present research, the aim was to study the views that teachers have on their self-efficacy. The aim of the proposed research is to study the level of didactic self-efficacy of pre-school teachers in schools in Athens, in terms 
of teaching strategies, classroom management, and student engagement. Specifically, the purpose of this research is to study what is responsible if something goes wrong in the classroom and how the teacher can provide solutions and help children reach knowledge and learning. However, the ultimate goal of the proposed research is to enrich the existing knowledge regarding the level of self-efficacy in pre-school teachers in Athens. These results will be useful because in this way the knowledge of the educational community will be enriched.

This topic piqued my interest because through everything I read about it, I realized that there are several shortcomings in the part of teaching self-efficacy of pre-school teachers. That is, what I realized from what I read and from what I have learned from my practice, I have understood that it is quite difficult, but also very important for the teacher to manage his class properly both in the educational work and in the study strategies but also in the student engagement as well. So I decided to study this phenomenon to see how pre-school teachers deal with these situations.

This research is important because through the teacher's self-efficacy the child can achieve proper management in learning and knowledge. It is also important to study why teaching self-efficacy is not something stable, but can be changed and differentiated by various factors such as school climate, family, and student behavior; and especially through the role that the teacher has in a classroom, a factor which in fact dominates the present research study [2].

Consequently, what one can understand is that teachers' self-efficacy is closely linked to a plethora of educational variables, that is, to the school structure with students but also to teachers themselves [3] so that there can be some data that will be useful to the teaching community, but also to science.

As can be seen from the research mentioned in the literature review, it is understood that in relation to teacher self-efficacy, teaching strategies, classroom management and student involvement, there is a great lack of knowledge in kindergarten and pre-school education in general. That happens because, as the research that has been done so far has shown, the data of the self-efficacy of the teacher who enters a kindergarten class have not been studied in depth and thus there are not correspondingly many research data [4]. So this issue needs study and investigation. That is why some questions have been asked, so that they can be answered through the research proposal.

How do teachers evaluate study strategies in their classroom?

How do teachers evaluate the level of self-perception according to student involvement?

How do teachers evaluate the management of their classroom?

$>$ Is there a correlation between teachers' self-perception among the studied sub-scales (teaching strategies-classroom management-student involvement)?

Following this research, the bibliographic data on which the student relied to prepare this paper will be reported. More specifically, reference was made to the 
theoretical background of self-efficacy and its characteristics. Research that is relevant to this topic was then presented in a research context. Then there will be the correlation and recognition of some problems that may exist. In the next chapter, data on research methodology are reported and the tools used to achieve it are recorded. In addition, what has been analyzed is moral issues. This chapter discusses the principles of ethics and ethics, access, acceptance as well as consensus and trust.

In more detail, the student's data will be reported in detail, what exactly she is looking for and how she will be able to safely secure the data collected by the people who agreed to participate in the research. There will also be an analysis of the results obtained from the collection of questionnaires, which will be commented on based on the research used in the bibliographic review chapter. Finally, there will be the conclusions of this research which will prove the value and usefulness of this research, but also the possible shortcomings or problems that may have occurred during its elaboration.

\section{Theoretical Framework}

The two main pillars of research are teaching and self-efficacy. Teaching is defined as the science that has as its special branch the pedagogical research, that is, it is a science that deals with the pedagogical teaching. In general, however, it is the science that has as its general branch the Pedagogy and deals with the issues of teaching and learning [5]. Self-efficacy is also defined as the individual's own assessment of his or her ability to organize and execute an action plan that will help his or her students reach learning [6]. The fact that teacher Self-efficacy affects teaching and learning, both the teacher and the learner, has attracted the attention of the research educational community for decades [7]. It is therefore worth noting that Self-efficacy is a conceptual structure based on self-perception rather than the actual level of an individual's abilities [8].

But when it comes to teachers' Self-efficacy, it can be defined as "the degree to which a teacher believes they can influence the performance and behavior of students, especially those who have either difficulties or low learning motivations" [9]. That is, teacher effectiveness is associated with promoting motivation in students, increased self-esteem [10] and highlighting positive attitudes and perceptions about school [11].

Of course, in addition to these, teaching Self-efficacy has some parameters, such as: study strategies, classroom management and student engagement. That is, in order for a teacher to be effective and meet his/her expectations, he/she must be able to manage the classroom in such a way as to cover the material he/she wants to produce, to give the children an understanding that they must obey rules, to be able to even involve all children in the activities they do and no one will be left out of the game and finally they will have to invent activities and constructions that will help the children to develop both mentally and physically, but also psychologically [12]. 


\subsection{Research Analysis}

Numerous studies have been conducted with participating teachers to measure teaching Self-efficacy at various levels of education in which various tools have been used. In general, teacher Self-efficacy is referred into the literature as the degree to which a teacher is convinced that he or she has the ability to influence the performance of his or her students [13].

Also with this term as stated by Zee and Koomen [14], every teacher can and does judge himself subjectively, because how right and good a teacher can be may change due to changes that may occur in his life. Of course, Self-efficacy also deals with power, generalization and level, as Bandura states [6]. All of this has to do with the level of difficulty, the power it has to do with a person's ability to carry out a task successfully, and finally that the generalization deals with the activities that the person does and is related to his abilities [6].

Even Self-efficacy, as Rapti [15] reports, is directly related to self-perception in relation to dealing with problem behaviors. That is, self-perception initially has to do with teachers' judgment of their ability to be effective toward their students, and it has to do with how they manage their students when they are not cooperative and react to whatever their teachers say or do. This research aimed to show the link that has been established between self-perception and Self-efficacy for problem solving, such as children's behavioral problems within a classroom and problem solving and management by teachers.

In addition, Andreou [16] reports more on educational effectiveness. More specifically, he states that teachers' Self-efficacy helps children to have a better educational background, because their teachers try harder. This is achieved through teaching methods and strategies that ensure the student's freedom and autonomy. Self-efficacy has also been linked to teachers' behavior, enthusiasm, determination, creativity, and willingness to work with their students [8].

Another research that has been done for Preschool education is that of Glynou [4], because it mainly refers to the self-efficacy that exists in the Municipal kindergartens. She mentions in more detail the relationship between the self-efficacy of preschool teachers and their occupational exhaustion. In other words, it theoretically states the concept of occupational exhaustion and the dimensions of Self-efficacy based on the Bandura model. As a professional exhaustion, he states that it is the relationship that people have with their work. Weakness occurs when there are problems between the person and his job. In other words, it is a threat that has emerged in recent years and can greatly affect a person's psychology. Teachers are greatly influenced by this and as a result they do not practice their profession properly and thus the educational work remains incomplete [17]. Glynou uses the Bandura model to describe Self-efficacy, which states that each person acts, thinks and feels differently. That's why Self-efficacy is associated with depression, anxiety, and despair. "In addition, people with low Self-efficacy are pessimistic about their achievements and personal development. In terms of thinking, a strong sense of Self-efficacy facilitates cognitive processes and performance in various actions, such as the decision-making process, academic per- 
formance, and professional development [18]". Teachers who have set high levels of Self-efficacy aim for goals that are achievable. So that if they fail, they will be able to find their mistakes and correct them.

Finally, Antoniou, Geralexis and Charitaki [19] have done equally important research, although he studied Self-efficacy in special education teachers. The aim of this research was to show the Self-efficacy of special educators through the variation of a questionnaire. Although it is limited, because these children cannot learn easily due to their circumstances. In order for a teacher to be effective then he/she must be very well organized and show great patience and apply new techniques so that he/she can face any difficulties that may be arisen. In addition, the effectiveness of teachers depends on emotional criteria such as stress and anxiety, it can also be affected by the exhaustion that a teacher may have suffered, but also by his gender. He also mentions that between the Self-efficacy of general and special education there are many commonalities both at the educational and professional level. However, it is obvious that not enough research has been done on special education and for this reason Geralexis [19] decided to study this phenomenon. In general, the research aims to help science design some training programs for kindergarten and kindergarten teachers so that they can improve their levels of Self-efficacy.

\subsection{Research Methodology}

Educational research is defined as the effort made by each researcher to get as close as possible to understanding the educational process and its effectiveness. In other words, educational research is an application that helps to study the educational process [20]. Of course, in order for research to be carried out, it is first necessary to have decided on the method to be followed. There are three types of methodologies: qualitative, quantitative and mixed. Quantitative research will be used in this research to ask a larger number of teachers. Specifically, quantitative studies are defined as research based primarily on data collection, which can be quantified and display their data in numbers on frequency tables, so that they can be compared with other tables through complex descriptive and inductive statistical analyzes [21].

As Kyriazopoulos and Samanda [22] report, the positives of this type of research are: the clear description of each object of research and that there is a demarcation of the variables. It also has high data reliability levels because they make controlled monitoring. This ensures the subjectivity of the results. It is even possible to use them for additional observation of the performance of the research subjects at another time. Finally, through the quantitative method, various discoveries are made about causes that are responsible for the changes that take place in society. In this research, the researcher usually uses Deductive reasoning, that is, the researcher starts from an already existing theory and tries to find an answer. The quantitative method, that is, uses numerical data to verify a hypothesis and so, it leads to generalizations and empirically grounded theories through research hypotheses [23]. 


\section{Research Tools}

\subsection{Questionnaire}

All research needs some tools to get it done. These tools are the interview, the observation and the questionnaire. In this research the tool used to conduct it is the questionnaire. Although there are several definitions, the questionnaire is defined as a general term that includes data collection techniques, where each respondent answers the same set of questions, in a predetermined order [24]. Questionnaires are one of the most important means of collecting data and information, mainly used for research on pedagogy, psychology and sociology. The questionnaire also asks all individuals to answer the same questions so that descriptive and explanatory data can be collected, data on attitudes, behaviors, characteristics and attitudes [21]. The main advantages of the questionnaires are that: they are cheaper, they can be sent to a large number of people, they are easier to create, the respondents can express themselves freely due to lack of direct communication, the ways of analyzing the material are standard, the researchers are not affected by the answers, the answers given can be quantified and finally is the least time consuming method [24].

The questionnaire to be used is the "Teaching Efficacy Instrument: Teacher's Sense of Efficacy Scale [TSES]" [1] and will be given to at least forty (40) teachers. It concerns teachers because the research aims to show the teacher's Self-efficacy. That is, it has to do with how much he/she considers himself/herself to be coping with the needs of a class. The data collected will be mainly about Self-efficacy. While consequently the ways in which the teacher tries to help the children and in general the climate that prevails between the teachers themselves, but also between teachers and children. In more detail, what is being researched is how much each teacher considers to be doing the best job and how many open horizons he has to be able to pique the interest of his students. But one more thing that this research is looking for is the relationships that teachers have with each other and whether they are trying together to solve any problems that may arise. Also, this questionnaire consists of 24 closed-ended questions, which will be illustrated with the Likert scale, which is divided into five categories, with the first "does not characterize me at all" and the fifth "characterizes me completely". Finally, what should be made clear through this research and the use of questionnaires is the reliability that should be between 1 and 0.90 . However, more specifically, the reliability indicators of repeated measurements for scale propositions ranged from 0.41 to 0.89 and the internal consistency reliability for subscales ranged from 0.78 to 0.82 [25].

\subsection{Sampling}

As is already known from the literature, sampling is divided into two categories, the first is the Probability Sampling and the second is the Non-Probability Sampling [26]. More generally, however, people who are involved in research are defined as a sample. In the research conducted, the symptomatic sampling method 
was used. Symptomatic sampling is defined as the sample that meets the characteristics and is immediately available to the researcher [27]. This methodology is the simple, but also accurate method, because it ensures the achievement of the representativeness of the sample [22]. That is, the sample is the number of people who answer the questionnaires, participate in the interviews and are the subject of the researcher's observation [28]. That is, the questionnaires will be given to fifty (40) teachers who will be mostly women in the age group of twenty (20) to fifty (50) and who are asked to express their views by answering the questionnaire with honesty and objectivity so that properly investigate the effectiveness of teachers.

\subsection{Research Process}

The data collection, as already defined by the Ethics Form, took place within a month, from February 3 to March 3, and the data collected should have been processed by March 23. The collection of this data was done through the framework of my internship, but also by well-known preschool teachers who helped me with great willingness.

The data was collected in an easy way, because I took back all the questionnaires I gave, except for some exceptions where people did not manage to answer them due to workload. The steps that followed were simple and specific, I first printed out the questionnaires and distributed them first to the station where I do my internship and then I started sharing them outside as well. In order for them to return them to me, I had given them 15 days so that they would have time to answer my questionnaire honestly.

The results to be quantified and analyzed to draw a conclusion were used the SPSS program which helps the student to analyze his data through an easy and passable way so as to avoid errors that can be fatal for research.

\section{Issues of Validity and Reliability}

One of the most important issues in conducting a survey is its validity and reliability in terms of its results. A survey will only be validated when it comes to reliable data that comes in direct contact with what the researcher is supporting [29]. In general, however, validity and reliability are the most important factors in effective quantitative research. Also, a tool can be considered reliable when it can and does give the theoretical meaning that is the reason for its construction. This is controlled by the Cronbach Alpha reliability factor. These values range from 0.00 to 1.00 , with a reliable measurement of 0.80 [30].

In this study, the validity and reliability of quantitative data are ensured through careful sampling by a representative population of the sample (at least 40 preschool teachers). This sample is appropriate because it is representative of the results analysis [31]. Besides, the sampling method we followed in the research is "convenient" or random sampling, in which the researcher selects the closest individuals to serve as respondents and this process continues until the required 
sample size is obtained [32] [27]. Our sample is considered representative, as we selected the specific individuals for their characteristics, so that we can reach conclusions for the whole. It is also considered appropriate because it is aware of the educational issues we are exploring and voluntarily participates in the study [32] [33]. The validity and reliability of the quantitative results can also be ensured by the research tool itself [34], as well as the Teaching Efficacy Instrument: Teachers' Sense of Efficacy Scale [TSES] [1] is an official structured, numerically measurable and tested research tool for its validity and reliability.

\section{Issues of Ethics}

In order for research to be conducted a very important part that needs to be taken care of is the one with the ethical issues. That is, the researcher should be very careful about the people who will take part in this research. In particular, individuals need to be aware of the nature of the research, the context in which it will take place, the procedures to be followed, the method by which the data will be collected and the type of data, and finally what will be done with the data which will have been collected. All this must be defined from the beginning because it is a very delicate matter and some possible mistake can be fatal for the research [30].

In general, research should be conducted respecting science, academic freedom in life, nature and the environment, human dignity, personal autonomy, human biological and spiritual integrity, intellectual property and personal data. The survey should avoid any discrimination against ethnicity, race, language, gender, religion, privacy, physical fitness, financial status or other factors unrelated to scientific research. The methodology that the researcher will follow in order to get the right results, which will be able to be verified and quantified, should also be known. Of course, research on humans is particularly important because they impose certain directions [27].

Also, no research related to pedagogy in humans can be done without informing the individual and having written consent for the purpose of the research and the potential risks. That is, if individuals agree to participate in the research then there must be the consent signed with which they show that they know and accept everything that will be done in the research. Of course, the research authorities have an important role to play in protecting all stakeholders. In addition, as far as social research is concerned, researchers should pay attention to and respect political and individual role differences, i.e.: age, gender, race, minority, origin, religion, disability, language and financial level [35].

In addition, ethics must be ensured beyond validity and reliability. This is because these studies focus on man and his behavior, and therefore must follow certain rules of ethics. More specifically: a) individuals are not required to participate in research and are not oppressed in any way, b) all the issues and purposes that the research is called upon to solve should be known, c) do not endanger the lives of the participants, $d$ ) researchers cannot take advantage of a 
person's disability, e) all opinions are accepted regardless of whether the researcher agrees and $f$ ) the results of the research must first be communicated to those individuals who participated in its conduct and be aware that these results will be protected and will not be altered [21].

Finally, what the researcher should do to be in the right direction throughout the research is to give all his/her personal information, such as: email and phone number, so that if he/she will be needed by one of the people who have taken part in research to be able to find him/her. It should also give these people a great way to understand how important it is to be involved in research and how much they will help science by giving a little bit of their time to it. However, what the researcher should have explained to the people who are going to take part in the research is that there is no way that their personal data will come out, nor will they be in danger. But if the individuals themselves consider that they cannot continue then they can leave without any phobia or hesitation [36].

\section{Result Analysis}

The main focus and purpose of this research is to investigate and study the teaching effectiveness in terms of student engagement, study strategies and classroom management. This was achieved through the analysis of the questionnaires. This analysis was done through the SPSS statistical program.

\subsection{Data Analysis-Descriptive Analysis-Demographics}

A total of 40 Preschool teachers took part in this research of whom all 40 were women. This is already shown in Table 1.

\section{Years of Work:}

Regarding the years of work, as it seems very good from Table 2, most of the teachers ranged from 0 to 5 years, i.e. this percentage reached $70 \%$. The $24 \%$ was reached by the teachers who had more than 10 years of previous service. While from 5 to 10 years it was the smallest percentage, which reached only $6 \%$.

\section{Teacher's Age:}

The age of the teacher ranged from 20 to 55, as these data show that the average of the teachers was 31, while the standard deviation was 10.1. More specifically, 50 women with a mean age of 31 years participated in this study (T.A. = \pm 10.1 ). The youngest participant was 20 years old and the oldest 55 . The majority of the participants, 35 out of 50, had a few years of service, specifically from 0 to 5 years $(70.0 \%)$, from 6 to 10 years had the $6 \%$ and over 10 years $12 \%$.

Table 1. Gender frequency table.

\begin{tabular}{ccc}
\hline Sex & Frequency & Rate \\
\hline Male & 0 & $0 \%$ \\
Female & 50 & $100 \%$ \\
Total & 50 & $100 \%$ \\
\hline
\end{tabular}


Table 2. Frequency table for pre-service years.

\begin{tabular}{ccc}
\hline Years of Service & Frequency & Rate \\
\hline $\mathbf{0}-\mathbf{5}$ years & 35 & $70 \%$ \\
$\mathbf{5}-\mathbf{1 0}$ years & 3 & $6 \%$ \\
$\mathbf{1 0}-$ up & 12 & $24 \%$ \\
Total & 50 & $100 \%$ \\
\hline
\end{tabular}

\subsection{Descriptive Analysis-Teacher Self-Effectiveness Questionnaire}

The Teaching Efficacy Instrument: Teachers' Sense of Efficacy Scale (TSES) [1] is a scale that includes 24 questions. This scale consists of three sub-scales of teacher effectiveness, which are teaching strategies, classroom management and student engagement. So what the respondents have to do is to state the degree to which they consider that each of the sentences characterizes them using a five-point Likert scale, which starts with $1=$ does not characterize me at all and ends up with $5=$ characterizes me completely. This scale is quite reliable, because it seems that the reliability indicators range from 0.41 to 0.89 points and the reliability of internal consistency for sub-scales ranges from 0.78 to 0.82 points [25].

As for the first sub-scale, the teaching strategies, it is created by adding the questions with numbers $7,10,17,18,20,23$, and 24 . For the second sub-scale, the classroom management, we add the questions with number 3, 5, 8, 13, 15, 16, 19 and 21 , while for the latter, i.e. for the involvement of students, it is enough to remove the remaining questions.

\begin{tabular}{cc}
\hline \multicolumn{2}{c}{ Gronbach's Alpha } \\
\hline Student Involvement & 0.796 \\
Teaching Strategies & 0.873 \\
Classroom Management & 0.842 \\
Scale of Didactic Self-Efficacy & 0.917 \\
\hline
\end{tabular}

\subsection{Research Questions}

Research Question 1: How do teachers evaluate teaching strategies in their classroom?

As mentioned earlier, the questions in the questionnaire that answer this question are: $7,10,11,17,18,20,23,24$. As can be seen from the answers given, the teaching strategies are at a fairly good level. This will be best seen through the answers given to these questions.

Question 7: 32 out of 50 people, 67\% of the sample answered that they do quite well.

Question 10: As can be seen here, 60\% answered that they are doing quite well. 


\begin{tabular}{|c|c|c|c|c|c|c|c|}
\hline & Not at all & Very little & A little bit & Enough & Absolutely & $\begin{array}{l}\text { Average } \\
\text { Price }(\mathrm{m})\end{array}$ & $\begin{array}{c}\text { Typical } \\
\text { Deviation (s.d.) }\end{array}$ \\
\hline $\begin{array}{l}\text { 7) How well can you answer difficult } \\
\text { questions for your students? }\end{array}$ & $0 \%$ & $2 \%$ & $8 \%$ & $58 \%$ & $32 \%$ & 3.96 & 0.699 \\
\hline $\begin{array}{l}\text { 10) To what extent can you calculate students' } \\
\text { understanding of what you have taught? }\end{array}$ & $0 \%$ & $2 \%$ & $18 \%$ & $60 \%$ & $20 \%$ & 3.98 & 0.685 \\
\hline $\begin{array}{l}\text { 11) To what extent can you ask good } \\
\text { questions for your students? }\end{array}$ & $0 \%$ & $2 \%$ & $14 \%$ & $46 \%$ & $38 \%$ & 4.20 & 0.756 \\
\hline $\begin{array}{l}\text { 17) How much can you do to tailor your } \\
\text { lessons to each student individually? }\end{array}$ & $0 \%$ & $6 \%$ & $28 \%$ & $48 \%$ & $18 \%$ & 3.78 & 0.815 \\
\hline $\begin{array}{l}\text { 18) To what extent can you use a range of } \\
\text { evaluation strategies? }\end{array}$ & $2 \%$ & $4 \%$ & $30 \%$ & $48 \%$ & $16 \%$ & 3.72 & 0.858 \\
\hline $\begin{array}{l}\text { 20) To what extent can you provide an } \\
\text { alternative explanation or example when } \\
\text { students are confused? }\end{array}$ & $0 \%$ & $2 \%$ & $6 \%$ & $46 \%$ & $46 \%$ & 4.36 & 0.693 \\
\hline $\begin{array}{l}\text { 23) How well can you implement alternative } \\
\text { strategies in your classroom? }\end{array}$ & $0 \%$ & $4 \%$ & $18 \%$ & $60 \%$ & $18 \%$ & 3.92 & 0.724 \\
\hline $\begin{array}{l}\text { 24) How well can you provide appropriate } \\
\text { challenges for very capable students? }\end{array}$ & $0 \%$ & $2 \%$ & $8 \%$ & $56 \%$ & $34 \%$ & 4.22 & 0.679 \\
\hline
\end{tabular}

Question 11: As can be seen here, $46 \%$ answered that they are doing quite well.

Question 17: As can be seen here, $48 \%$ answered that they are doing quite well.

Question 18: As can be seen here, $48 \%$ answered that they are doing quite well.

Question 20: As can be seen here, $46 \%$ answered that they do quite well, but in this particular question, the other $46 \%$ answered that they do it perfectly.

Question 23: As it seems here, 60\% answered that they manage quite a bit.

Question 24: As it seems here, 56\% answered that they are doing quite well.

As can be seen from all these answers, preschool teachers place a lot of emphasis on teaching strategies so that they can help their children reach knowledge.

Research Question 2: How do teachers evaluate the level of self-perception according to student involvement?

As mentioned earlier, the questions in the questionnaire that answer this question are: $1,2,4,6,9,12,14,22$.

Question 1: As it seems here, $54 \%$ answered that they are doing quite well.

Question 2: As it seems here, 54\% answered that they are doing quite well.

Question 4: As can be seen here, $40 \%$ answered that they do it perfectly, while $36 \%$ said that they do it quite well. 


\begin{tabular}{|c|c|c|c|c|c|c|c|}
\hline & Not at all & Very little & A little bit & Enough & Absolutely & $\begin{array}{l}\text { Average } \\
\text { Price }(\mathrm{m})\end{array}$ & $\begin{array}{c}\text { Typical } \\
\text { Deviation (s.d.) }\end{array}$ \\
\hline $\begin{array}{l}\text { 1) How much can you do to be understood } \\
\text { by the most difficult students? }\end{array}$ & $0 \%$ & $0 \%$ & $12 \%$ & $54 \%$ & $34 \%$ & 4.22 & 0.648 \\
\hline $\begin{array}{l}\text { 2) How much can you do to help your } \\
\text { students think critically? }\end{array}$ & $0 \%$ & $0 \%$ & $8 \%$ & $54 \%$ & $38 \%$ & 4.30 & 0.614 \\
\hline $\begin{array}{l}\text { 4) How much can you do to mobilize students } \\
\text { who show reduced interest in schoolwork? }\end{array}$ & $0 \%$ & $4 \%$ & $20 \%$ & $36 \%$ & $40 \%$ & 4.12 & 0.872 \\
\hline $\begin{array}{l}\text { 6) How much can you do to convince students } \\
\text { that they can do well in school? }\end{array}$ & $0 \%$ & $2 \%$ & $2 \%$ & $46 \%$ & $50 \%$ & 4.44 & 0.644 \\
\hline $\begin{array}{l}\text { 9) How much can you do to help your } \\
\text { students appreciate learning? }\end{array}$ & $0 \%$ & $0 \%$ & $18 \%$ & $46 \%$ & $36 \%$ & 4.18 & 0.720 \\
\hline $\begin{array}{l}\text { 12) How much can you do to enhance } \\
\text { students' creativity? }\end{array}$ & $0 \%$ & $4 \%$ & $12 \%$ & $54 \%$ & $30 \%$ & 4.10 & 0.763 \\
\hline $\begin{array}{l}\text { 14) How much can you do to improve your } \\
\text { understanding of a failed student? }\end{array}$ & $0 \%$ & $0 \%$ & $20 \%$ & $46 \%$ & $34 \%$ & 4.14 & 0.729 \\
\hline $\begin{array}{l}\text { 22) To what extent can you help families in } \\
\text { turn help their children do well in school? }\end{array}$ & $2 \%$ & $2 \%$ & $22 \%$ & $54 \%$ & $20 \%$ & 3.88 & 0.824 \\
\hline
\end{tabular}

Question 6: As can be seen here, 50\% answered that they do it perfectly, while $46 \%$ answered that they do it quite well.

Question 9: As can be seen here, 36\% answered that they are doing perfectly well, while $46 \%$ said that they are doing quite well. However, in the specific question, the percentage that answered a little was quite high, i.e. it reached $18 \%$.

Question 12: As can be seen here, 54\% answered that they are doing quite well.

Question 14: As can be seen here, 34\% answered that they do it perfectly, while $46 \%$ said that they do it quite well. However, in the specific question, the percentage that answered a little was quite high, i.e. it reached $20 \%$.

Question 22: As it seems here, $20 \%$ answered that they succeed completely, while $54 \%$ that they succeed quite a lot. However, in the specific question, the percentage that answered a little was quite high, i.e. it reached $22 \%$.

As the teachers pointed out in this question, although they try to raise the levels of student engagement in their classroom, they do not succeed and very well. This is clear because in these answers the level has increased a lot with the answer "a little". Of course, there are several teachers who succeed.

Research Question 3: How do teachers evaluate the management of their classroom?

As mentioned earlier, the questions in the questionnaire that answer this question are: $3,5,8,13,15,16,19,21$.

Question 3: As can be seen here, 22\% answered that they do it perfectly, while $44 \%$ said that they do it quite well. As at high levels is the littlebit which reached $24 \%$.

Question 5: As can be seen here, 18\% answered that they do it perfectly, while $58 \%$ said that they do it quite well. While the little bit here again reached $22 \%$. 


\begin{tabular}{|c|c|c|c|c|c|c|c|}
\hline & Not at all & Very little & A little bit & Enough & Absolutely & $\begin{array}{l}\text { Average } \\
\text { Price }(\mathrm{m})\end{array}$ & $\begin{array}{c}\text { Typical } \\
\text { Deviation (s.d.) }\end{array}$ \\
\hline $\begin{array}{l}\text { 3) How much can you do to control the } \\
\text { disturbed behavior in the classroom? }\end{array}$ & $0 \%$ & $2 \%$ & $24 \%$ & $44 \%$ & $30 \%$ & 4.02 & 0.795 \\
\hline $\begin{array}{l}\text { 5) To what extent can you make your } \\
\text { expectations of student behavior clear? }\end{array}$ & $0 \%$ & $2 \%$ & $22 \%$ & $58 \%$ & $18 \%$ & 3.92 & 0.697 \\
\hline $\begin{array}{l}\text { 8) How well can you impose daily procedures } \\
\text { so that the activities run smoothly? }\end{array}$ & $0 \%$ & $2 \%$ & $8 \%$ & $58 \%$ & $32 \%$ & 4.20 & 0.670 \\
\hline $\begin{array}{l}\text { 13) How much can you do to persuade } \\
\text { children to follow the rules of the classroom? }\end{array}$ & $2 \%$ & $16 \%$ & $40 \%$ & $42 \%$ & $0 \%$ & 4.20 & 0.857 \\
\hline $\begin{array}{l}\text { 15) How much can you do to calm a student } \\
\text { who is naughty or noisy? }\end{array}$ & $0 \%$ & $2 \%$ & $14 \%$ & $52 \%$ & $32 \%$ & 4.14 & 0.729 \\
\hline $\begin{array}{l}\text { 16) How well can you impose a classroom } \\
\text { management system for each group of } \\
\text { students? }\end{array}$ & $0 \%$ & $8 \%$ & $18 \%$ & $50 \%$ & $24 \%$ & 3.90 & 0.863 \\
\hline $\begin{array}{l}\text { 19) To what extent can you prevent some } \\
\text { troubled students from destroying an entire } \\
\text { lesson? }\end{array}$ & $2 \%$ & $4 \%$ & $12 \%$ & $32 \%$ & $20 \%$ & 3.94 & 0.818 \\
\hline $\begin{array}{l}\text { 21) How well can you deal with vindictive } \\
\text { students? }\end{array}$ & $0 \%$ & $10 \%$ & $24 \%$ & $44 \%$ & $22 \%$ & 3.78 & 0.910 \\
\hline
\end{tabular}

Question 8: As can be seen here, 32\% answered that they do it perfectly, while $58 \%$ said that they do it quite well.

Question 13: As can be seen here, $42 \%$ answered that they do it perfectly, while $40 \%$ answered that they do it quite well.

Question 15: As can be seen here, 32\% answered that they do it perfectly, while $52 \%$ said that they do it quite well.

Question 16: As can be seen here, 24\% answered that they succeed completely, while $50 \%$ answered that they do quite well.

Question 19: As it seems here, 20\% answered that they do it perfectly, while $62 \%$ answered that they do it quite well.

Question 21: As it seems here, 22\% answered that they do it perfectly, while $44 \%$ said that they do it quite well. While the little bit here reached $24 \%$.

Finally, as seen in this question, preschool teachers try to manage their classroom as best they can so that they can help their students reach the highest possible level of knowledge. However, this will only happen if the teacher manages to deal with any difficulties encountered by the disobedient students. So it seems that teachers largely succeed and manage their classroom properly. Of course, there are also cases where they do not succeed as well as it appeared from some answers.

Research Question 4: Is there a correlation between teachers' self-perception among the studied sub-scales (classroom teaching-management strategies-student involvement)?

As can be clearly seen from the previous analysis, all sub-scales are interconnected. This is understood from the answers given by preschool teachers. More 
analytically, the analysis of the questionnaires showed that in order for there to be a significant level of Self-efficacy, all scales must be at a high level. That is, student engagement, classroom management, and teaching strategies should be on an equal footing to ensure that the teacher has done his or her job properly.

So what emerges from all the analysis is that teaching Self-efficacy is not affected by either gender or age, but what can change the data a bit is the years of work which, as they have shown, the more work they have done over the years the more up-level their self-efficacy was.

In more detail, as can be seen from the analysis made in the findings, it seems that the correlation is positive and strong. Specifically, the student involvement correlation coefficient with the Teaching Strategies takes the value 0.758. The correlation coefficient of Classroom Management and Student Involvement has a value of 0.777 . Also, the correlation coefficient of Classroom Management and teaching strategies is 0.777 .

\section{Descriptive statistics}

\begin{tabular}{ccccccc}
\hline & N & Min. & Max. & Mean & Std. Deviation & Variance \\
\hline engeagments & 50 & 24 & 40 & 4.172 & 3.948 & 15.587 \\
strategies & 50 & 19 & 40 & 4.017 & 4.328 & 18.735 \\
management & 50 & 17 & 40 & 4.012 & 4.705 & 22.133 \\
Valid N (listwise) & 50 & & & & & \\
\hline
\end{tabular}

\section{Research Questions-Commentary}

1) How do teachers evaluate teaching strategies in their classroom?

The average value of teaching strategies was found to be 4,017 points, which is a high value according to the literature, so preschool educators have highly evaluated their effectiveness in using teaching strategies.

2) How do teachers evaluate the level of self-perception according to student involvement?

Similarly, the average price for student engagement was found to be high and equal to 4,172 points, so Preschool educators who were the sample of the present study, highly evaluate the teaching effectiveness of the strategies they use regarding student engagement.

3) How do teachers evaluate the management of their classroom?

The average classroom management score was found to be 4,012 points, which is described as high, according to the literature, and so Preschool educators who participated in this study highly assessed the effectiveness of the strategies they use to manage the classroom.

4) Is there a correlation between teachers' self-perception among the studied sub-scales (teaching strategies_classroom management-student involvement)?

The average value resulting from the correlation is 30.21 points. This shows that Preschool educators have quite high levels of Self-efficacy and can therefore adequately address all of their issues. 
As it has been shown, the literature presented in the previous chapter shows that teaching Self-efficacy is at an increased level in both primary, secondary, special education and pre-school teachers. This is made clear by the research questions and answers provided by all of these studies. More specifically, three of the five surveys used to document the present had used the Teaching Efficacy Instrument: Teacher's Sense of Efficacy Scale [TSES] [1] as their research tool.

So this shows that this tool is valid and reliable. However, this questionnaire in preschool education has been used only once in terms of research analyzed in the present study. But in addition to using the same questionnaires, their research questions used in these surveys were very similar. So this has resulted in researchers being able to control with much greater ease and bibliographically documented whether what they find can be supported.

As it turns out, in terms of teaching Self-efficacy, its levels in this study were just as high as the other studies used in this study. In other words, this weighted tool was used in other research and showed that its reliability is correct, because the teaching Self-efficacy at all levels of education is almost the same. So the findings of this study confirm the previous research that has been done on this issue and let it be done at different levels.

\section{Commentary and Link of the Mentioned Researches with the Present Research}

Of course, in addition to the research that was used, which had a lot in common with each other, they were found to have a lot in common with the present research. More specifically, most of these surveys, like mine, used similar research questions, and one of the two tools needed to conduct their research was the Teaching Efficacy Instrumental Effective Instruction: Teacher's Sense of Teacher Self-Efficacy Instruction: [TSES] [1] which was also used in the present study. The research that used this tool was by Antoniou [19] and Glynou [4]. However, it seems that one of the five surveys was the one that best suited the present, because it was also done in preschool teachers, this research is by Glynou [4], which took 120 preschool teachers to conduct (2017).

But beyond the commonalities of these studies, there are some differences. Initially the first and main difference with the four of the five surveys that have been analyzed is the individuals in whom the research tools were shared. In other words, Andreou [16] needed 139 people who were high school teachers to conduct his research, Antoniou [19] needed 200 special education teachers. Rapti [15], on the other hand, needed 100 primary school teachers and finally Nieto needed general education teachers. Another difference in these surveys compared to the present survey is that almost all other surveys had two research tools in relation to the specific survey that had only one.

\section{Adding Knowledge to Pre-Existing One}

As is clear from all that has been mentioned in this dissertation in science, these findings may be useful. This is made clear by the fact that there has not been 
much research on the teaching self-efficacy of preschool teachers, neither in the Greek literature, nor in the foreign one. This is made clear by the research that has been used to support this research. More specifically, one in five surveys used concerned pre-school teachers, the rest referred to teachers and one to special education teachers.

\begin{tabular}{ccccc}
\hline \multicolumn{5}{c}{ Correlation of the sub-scales of Teaching Self-Efficacy } \\
\hline & & $\begin{array}{c}\text { Student } \\
\text { Involvement }\end{array}$ & $\begin{array}{c}\text { Teaching } \\
\text { Strategies }\end{array}$ & $\begin{array}{c}\text { Classroom } \\
\text { Management }\end{array}$ \\
\hline Student & Pearson Correlation & 1 & $0.758^{* *}$ & 0.777 \\
Involvement & Sig. (2-tailed) & 0.000 & 0.000 & 0.000 \\
& $\mathrm{~N}$ & 50 & 50 & 50 \\
\hline Teaching & Pearson Correlation & $0.758^{* *}$ & 1 & $0.777^{* *}$ \\
Strategies & Sig. (2-tailed) & 0.000 & & 0.000 \\
& $\mathrm{~N}$ & 50 & 50 & 50 \\
\hline Classroom & Pearson Correlation & $0.777^{* *}$ & $0.777^{* *}$ & 1 \\
Management & Sig. (2-tailed) & 0.000 & 0.000 & 0.000 \\
& $\mathrm{~N}$ & 50 & 50 & 50 \\
\hline
\end{tabular}

**. Correlation is significant at the 0.01 level (2-tailed).

\section{Conclusions}

The preschool teacher does psycho-pedagogical work, because every day he experiences various emotions in the classroom. These feelings are sometimes positive and sometimes bring the feeling of frustration and applause. That happens because the teacher is a carrier of a special professional capacity. Also, this profession can be characterized by intense social action, because every day it comes in contact with a multitude of personalities and environments and thus should have proper management in both relationships and self-efficacy [37].

As mentioned earlier, the teacher's self-efficacy can be affected by both stress and psychological fatigue, and this results in occupational exhaustion, which greatly affects professional development and effectiveness of the teacher and thus the quality of the lesson decreases [38]. All of these elements as well as demographics are the measures through which the level of didactic Self-efficacy is revealed [39].

So the main goal of this work is to study the teaching Self-efficacy that pre-school teachers have. This research will be conducted through targeted research where the results will help enrich scientific research. They will also help to develop some future research.

As can already be seen from the entire dissertation, this educational research was very useful in the scientific community, because it offered further knowledge in the part of teaching Self-efficacy that was incomplete in terms of pre-school teachers in Athens. In other words, this small-scale survey showed that kindergarten teachers in Athens have a fairly high Self-efficacy index.

Of course, as this can be seen from the research questions of this work, it is that pre-school teachers place more emphasis on the part of classroom management, than on student involvement and finally on teaching strategies. This is evident from the answers given by the teachers [40]. 


\section{Suggestions and Restrictions}

In the present study, an attempt was made through the appropriate research tool-questionnaire, data collection by preschool educators and statistical analyzes to investigate and answer research questions related to the perception of self-efficacy of preschool teachers in relation to three important sub-scales: student engagement, teaching strategies and classroom management.

However, as mentioned above, what bothered me about conducting this research was the small sample of teachers I managed to collect, that is, my sample was 50 teachers and I had a hard time collecting these questionnaires. However, the positive thing about this situation is that the answers given by these people and through their honesty helped me to produce well-documented results.

Another limitation was that the questionnaire was self-reporting, meaning that deviations from the actual mood and attitude of teachers that may be due to the conscious or unconscious intention of participants not to express their image with true beliefs could not be avoided regarding to their answers. Of course, the tool was valid and reliable and the participation was voluntary.

Another limitation of this research was the total number of volunteers in research, i.e. the inability to compare the general characteristics of the participants with those who did not participate, this is due to the inability to assess personal data and beliefs with the decision to participate in the research.

In addition, the distribution and collection of questionnaires took place after the Christmas holidays. So, this may have damaged the results, because the teachers returned to work after 15 days with a much better mood than before.

\section{Future Research}

From the research of the studies and the bibliographic review that was done earlier in the present work, it was found that a large number of researches have been carried out that have studied the phenomena of the teaching Self-efficacy of teachers both in Greece and internationally. Teacher self-efficacy continues to be a highly researched theoretical construct with great import. The fact that efficacious teachers positively impact student outcomes across multiple disciplines and contexts is reason alone to continue to pursue this somewhat elusive construct. More specifically, researchers need to continue to investigate ways to better understand how teacher self-efficacy affects other changes in teacher behavior and what other teacher characteristics influence teacher self-efficacy. This article attempts to explain one of the influences by researching the potential relationship between teacher self-efficacy and pedagogical conceptual change [41].

These researches are useful because they concern the value of recording attitudes and opinions, as well as identifying the problems faced by teachers of general and special education at all levels of education, through the evaluation of teaching Self-efficacy. Therefore, in the future it would be interesting to conduct a survey on a larger sample of educators, which will come from all geographical regions of Greece. Such research could produce results that could be generalized [42]. 
So, what is desirable for future research is: the introduction of other exploratory factors and correlations, such as stress, ambiguity and role conflict with the dimensions of didactic self-efficacy, occupational safety based on exhaustion, to be used and the qualitative method of data collection, so as to make a more complete record of the attitudes and beliefs that teachers have.

\section{Acknowledgements}

This study would not have been possible without the contribution of numerous people. We would like to thank the educational staff who took part in the research.

\section{Conflicts of Interest}

The author declares no conflicts of interest regarding the publication of this paper.

\section{References}

[1] Tschannen-Moran, M. and Hoy, A. (2001) Teacher Efficacy: Capturing an Elusive Construct. Teaching and Teacher Education, 17, 783-805. https://doi.org/10.1016/S0742-051X(01)00036-1

[2] Kyriakidis, L. and Antoniou, P. (2010) Educational Effectiveness Theoretical Models: Measuring School Effectiveness. In: Pasiardis, P., Ed., Change Management, School Efficiency and Strategic Planning, Vol. 1, Nicosia Publishing House, Nicosia, 3-12.

[3] Evers, W.J.G., Brouwers, A. and Tomic, W. (2002) Burnout and Self-Efficacy: A Study on Teachers' Beliefs When Implementing an Innovative Educational System in the Netherlands. British Journal of Educational Psychology, 72, 227-244. https://doi.org/10.1348/000709902158865

[4] Glynou, D. (2017) The Effect of Self-Efficacy on Burnout: The Case of Preschool Teachers in Primary Schools. Transfer Diplomatic Work. http://okeanis.lib.puas.gr/xmlui/bitstream/handle/123456789/4016/\%CE\%94\%CE\% 94\%CE\%95-14-321.pdf?sequence=1

[5] Kasimati, A. (2008) Introduction to Teaching Methodology-Educational Research Methodology. Ministry of National Education and Religions, Athens.

http://repository.edulll.gr/edulll/bitstream/10795/1095/3/1095_01_oaed_enotita07_ v04.pdf

[6] Bandura, A. (1997) Self-Efficacy, Control Exercise. W. H. Freeman and Company, New York.

[7] Gibson, S. and Dembo, M. (1984) Teacher Effectiveness, a Constructive Validation.

[8] Tschannen-Moran, M. and Woolfolk-Hoy, A. (2007) The Differential Antecedents of Self-Efficacy Beliefs on Novice and Experienced Teachers. Teaching and Teacher Education, 23, 944-956. https://doi.org/10.1016/j.tate.2006.05.003

[9] Guskey, T.R. and Passaro, P.D. (1994) Teacher Efficacy: A Study of Construct Dimensions. American Educational Research Journal, 31, 627-643.

https://doi.org/10.3102/00028312031003627

[10] Borton, W.M. (1991) Empowering Teachers and Students in a Restructuring School: A Teacher Efficacy Interaction Model and the Effect on Reading Outcomes. The Annual Meeting of the American Educational Research Association, Chicago, ERIC Document Reproduction Service No. 335341. 
[11] Miskel, C., McDonald, D. and Bloom, S. (1983) Structural and Expectancy Linkages within Schools and Organizational Effectiveness. Educational Administration Quarterly, 19, 49-82. https://doi.org/10.1177/0013161X83019001004

[12] Hellenic Education Portal (2006) Study Strategies. https://www.eduportal.gr/starthgikes-meleths

[13] Brouwers, A. and Tomic, W. (2000) A Timeless Study on Teacher Burnout and Self-Efficacy in Classroom Management. Teacher Training and Education, 16, 239-253. https://doi.org/10.1016/S0742-051X(99)00057-8

[14] Zee, M. and Koomen, H.M. (2016) Teacher Self-Efficacy and Its Effects on Classroom Processes, Student Academic Adjustment, and Teacher Well-Being: A Synthesis of 40 Years of Research. Review of Educational Research, 86, 981-1015. https://doi.org/10.3102/0034654315626801

[15] Rapti, A. (2007) Teachers' Perceptions of Their Effectiveness in Dealing with Behavior at School. Bachelor's Thesis, University of Thessaly, Trikala. https://docplayer.gr/49372775-Oi-antilipseis-ton-ekpaideytikon-shetika-me-tin-apo telesmatikotita-toys-na-antimetopizoyn-provlimata-symperiforas-sto-sholeio.html

[16] Andreou, Th. (2009) The Professional Development of Teachers and Its Relationship with Self-Efficacy and Their Perceptions to Motivate Students. Bachelor's Thesis, University of Thessaly, Trikala. https://ir.lib.uth.gr/xmlui/handle/11615/14304

[17] Tsiliptaris, A. (2002) Greek Pedagogical and Educational Research. Proceedings of the 2 nd Panhellenic Conference, Athens, 2-4 November 2000, 1-15.

[18] Schwerdtfeger, A., Konermann, L. and Schonhofen, K. (2008) Self-Efficacy as a Resource for Teacher Health Protection: A Biopsychological Approach. Psychology of Health, Athens. https://doi.org/10.1037/0278-6133.27.3.358

[19] Antoniou, A.S., Geralexis, I. and Charitaki, G. (2017) Special Educators' Teaching Self-Efficacy Determination: A Quantitative Approach. Psychology, 8, 1642-1656. https://file.scirp.org/pdf/PSYCH_2017083014545422.pdf https://doi.org/10.4236/psych.2017.811108

[20] Koul, L. (2009) Methodology of Educational Research. 4th Edition, Vikas Publishing House, New Delhi.

[21] Athanassiou, L. (2007) Methods and Technical Research in the Sciences of Education. Efyra, Ioannina.

[22] Kyriazopoulos, P. and Samanda, E. (2011) Diplomatic Research Methodology.

[23] Bryman, A. (2004) Social Research Methods. 2nd Edition, Oxford University Press, New York.

[24] Paraskevopoulos, I. (1999) Interpersonal and Interpersonal Adjustment Questionnaire. Ellinika Grammata, Athens.

[25] Stalikas, A., Triliva, S. and Roussi, P. (2012) Psychometric Tools in Greece. Pedio Publications, Athina.

[26] Katsillis, I. (2006) Inductive Statistics. Gutenberg, Athens.

[27] Cohen, L., Manion, L. and Morrison, K. (2008) Educational Research Methodology. Metaichmio, Athens.

[28] Javeau, C. (2000) Questionnaire Research, the Handbook of the Good Researcher. Translation: Katerina Tzannone-George.

[29] Bell, J. (2007) How to Write a Research Paper: Research Methodology Guide. Metaichmio, Athens.

[30] Nova-Kaltsouni, Ch. (2006) Social Research Methodology in Social Sciences. Gutenberg, Athens. 
[31] Morrison, K.R.B. (1993) Planning and Accomplishing School-Centred Evaluation. Peter Francis Publishers, Norfolk.

[32] Creswell, J. (2016) Research in Education: Design, Conduct and Evaluation of Quantitative and Qualitative Research (Translated by Kouvarakou, N.). Ion (Year of Publication of the Original 2005), Athens.

[33] Robson, C. (2010). Real-World Research-A Tool for Social Scientists and Professional Researchers (Translated by Dalakou, V., Vasilikou, K.). Gutenberg (1993 Edition), Athens.

[34] Ouzouni, Ch. and Nakakis, K. (2011) The Reliability and Validity of Measuring Instruments in Quantitative Studies. Nursing, 50, 231-239.

[35] Latinopoulos, P. (2010) The First Steps in Research. A Useful Guide for Young Researchers. Kritiki, Athens.

[36] University of Crete (2012) Research Code of Ethics.

[37] Scheerens, J. and Bosker, R.J. (1997) The Foundations of Educational Effectiveness. Pergamon, Oxford.

[38] Kokkinos, C.M. and Davazoglou, A.M. (2009) Special Education Teachers under Stress: Evidence from a Greek National Study. Educational Psychology, 29, 407-424. https://doi.org/10.1080/01443410902971492

[39] Näring, G., Briët, M. and Brouwers, A. (2006) Beyond Demand-Control: Emotional Labour and Symptoms of Burnout in Teachers. Work and Stress, 20, 303-315. https://doi.org/10.1080/02678370601065182

[40] Bania, T.A., Antoniou, A.S., Theodoritsi, M., Theodoritsi, I., Charitaki, G. and Billis, E. (2019) The Interaction with Disabled Persons Scale: Translation and Cross-Cultural Validation into Greek. Disability and Rehabilitation. https://doi.org/10.1080/09638288.2019.1643420

[41] Lee, B., Cawthorn, S. and Dawson, K. (2013) Elementary and Secondary Teacher Self-Efficacy for Teaching and Pedagogical Conceptual Change in a Drama-Based Professional Development Program. Teaching and Teacher Education, 30, 84-98. https://www.researchgate.net/profile/Bridget_Lee2/publication/257245765_Elementar y_and_secondary_teacher_self-efficacy_for_teaching_and_pedagogical_conceptual_c hange_in_a_drama-based_professional_development_program/links/5afb03f6458515 c00b6cb77f/Elementary-and-secondary-teacher-self-efficacy-for-teaching-and-pedago gical-conceptual-change-in-a-drama-based-professional-development-program.pdf https://doi.org/10.1016/j.tate.2012.10.010

[42] Sarikaya, İ., Töman, U. and Öztürk, M. (2018) Examining the Variables Predicting Attitudes towards Teaching Profession of Preservice Classroom Teachers. Acta Didactica Napocensia, 11, 129-141. https://doi.org/10.24193/adn.11.1.10 